\title{
気になる標識鳥情報 Topics of Banded Birds
}

山階鳥類研究所標識研究室に届けられた放鳥・回収記録のうち, 最新かつ興味深いあのをお知らせ します。

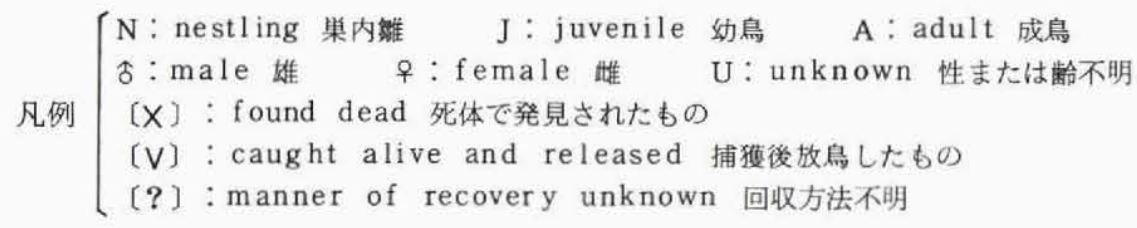

チュウサギ Egretta intermedia (100-33189)

放鳥 30 May. '85 (UN) 山口県熊毛郘平生町山田 Yamaguci Pref. ( $33^{\circ} 57^{\prime} \mathrm{N}, 132^{\circ}$ $066^{\prime}$ E) 小林繁樹

回収 $20 \mathrm{Mar}$. '87 中華人民共和国上海市崇明島 CHINA ( $\left.31^{\circ} 36^{\prime} \mathrm{N}, 121^{\circ} 18^{\prime} \mathrm{E}\right)$ (?) 本種の中国加らの初回収記録。

メタイチドリ Charadrius mongolus (030-03237)

放鳥 8 Sep. '74 (UA) 宮城県仙台市蒲生 Miyagi Pref. ( $38^{\circ} 15^{\prime} \mathrm{N}, 141^{\circ} 01^{\prime}$ E) 竹丸勝朗

回収 0 May. '85 中華人民共和国上海市崇明島 CHINA（ $\left.31^{\circ} 36^{\prime} \mathrm{N}, 121^{\circ} 18^{\prime} \mathrm{E}\right)$ 〔? 本種の 2 例目の外国回収。1例目む中国からの回収で放鳥地も同じ蒲生であった。

ソリハシシギ Xenus cinereus $(050-18682)$

放鳥 18 May. '83 (UA) 福岡県北九州市小倉南区曾根新田 Fukuoka Pref. ( $33^{\circ} 49^{\prime}$ N, $130^{\circ} 58^{\prime}$ E) 武下雅文

回収 24 Mar.'88 (UU) Roebuck Bay, Western Australia, AUSTRALIA (18 $\left.00^{\prime} \mathrm{S}, 122^{\circ} 22^{\prime} \mathrm{E}\right)$ (V)

本種のオーストラリア東部からの回収は過去 2 例あるが, オーストラリア北西部からはこれが初め ての記録である。

日本鳥類標識協会范 $3 ， 1988$
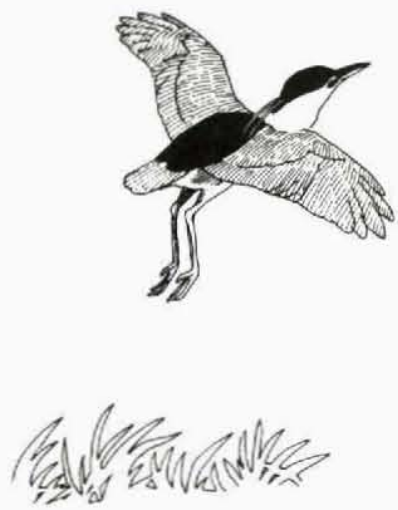
コヨシキリ Acrocephalus bistrigiceps (1A-06024)

放鳥 2 Aug. '88 (今 A) 青森県北津軽郡中里町岩木川河川敷 Aomori Pref. ( $40^{\circ} 59^{\prime}$ $N, 140^{\circ} 24^{\prime}$ E) 茂田良光

回収 7 Oct。'88 ( U J ) 山口県宇部市厚南区新開作西 Yamaguchi Pref. ( $33^{\circ} 57^{\prime} \mathrm{N}$, $131^{\circ} 12^{\prime}$ E) (V) 藤田勉再放鳥

福岡〜宮城間の移動（1982）に並ぶ長距離回収例。

コヨシキリ Acrocephalus bistrigiceps (1A-01989)

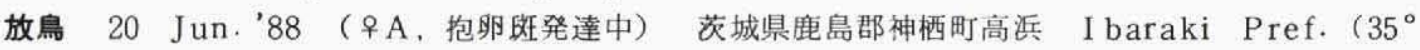
$\left.52^{\prime} \mathrm{N}, 140^{\circ} 38^{\prime} \mathrm{E}\right)$ 茂田良光 $\rightarrow 4 \mathrm{Jul}$. ' 88 同地にて茂田 Rp。

回収 7 Aug. '88 千葉県香取郡下総町小浮 Chiba Pref. ( $35^{\circ} 53^{\prime} \mathrm{N}, 140^{\circ} 22^{\prime}$ E)

（V〕河辺久男再放鳥

繁殖を終えた個体が短期間のうちに利根川沿いに $30 \mathrm{Km}$ 程上流へ移動した例として興味深い。

コヨシキリ Acrocephalus bistrigiceps (1A-01939)

放鳥 28 May. ' 88 ( 8 A) 東京都三宅村伊豆岬 Tokyo. ( $34^{\circ} 07^{\prime} \mathrm{N}, 139^{\circ} 30^{\prime}$ E) 茂田良光

これは，三宅島からの本種の新記録である（樋口広芳, 1988 私信）。

センタイムシクイ Phylloscopus ossipitalis (010-39213)

放鳥 4 May. ' 88 (UA) 山口県萩市見島 Yamaguchi Pref. ( $34^{\circ} 46^{\prime} \mathrm{N}, 1^{\circ} 01^{\circ}$ E) 暒畑哲二

回収 3 Sep.' 88 福井県福井市開発 Fukui Pref. ( $36^{\circ} 05^{\prime}$ N, $136^{\circ} 15^{\prime}$ E) (X) これは, 本種の初回収記録である。

シジュウカ Parus major (025-22915)

放鳥 11 Oct. '88 (ㅇ J) 北海道松前郡松前町白神岬 Hokkaido. ( $41^{\circ} 24^{\prime} \mathrm{N}, 1^{\circ}$ 12 ' E ) 佐藤理夫

回収 31 Oct. '8 8 東京都日野市程久保 Tokyo. ( $35^{\circ} 39^{\prime} \mathrm{N}, 139^{\circ} 25^{\prime} \mathrm{E}$ ) (X)

シジュウカラ Parus major (026-22413)

放鳥 10 Sep. '87 (우? J) 北海道苫小牧市樽前 Hokkaido. ( $42^{\circ} 36^{\prime} \mathrm{N}, 141^{\circ} 26^{\prime}$ E）三浦二郎

回収 26 J an. '8 8 福島県田村郡船引町新館 Fukushima Pref. ( $37^{\circ} 26^{\prime} \mathrm{N}, 140^{\circ} 35^{\prime}$ E) $[\mathrm{X}]$

この 2 例は, 本種の初めての長距離ダイレクト・リカバリーである。

このコーナーでは, バンダーの皆様からのホットな情報を集めています。初記録種はあちろん, 興 味あるリカバリー・データ等々, ありましたら是非御一報ください。回収担当・三田村まで。 